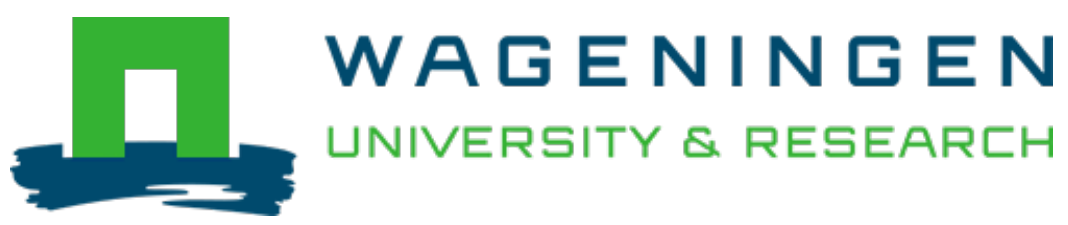

\title{
Materials with switchable radiometric properties: Could they become the perfect greenhouse cover?
}

\author{
Biosystems Engineering \\ Baeza, Esteban; Hemming, Silke; Stanghellini, Cecilia \\ https://doi.org/10.1016/j.biosystemseng.2020.02.012
}

This article is made publicly available in the institutional repository of Wageningen University and Research, under the terms of article $25 \mathrm{fa}$ of the Dutch Copyright Act, also known as the Amendment Taverne. This has been done with explicit consent by the author.

Article 25 fa states that the author of a short scientific work funded either wholly or partially by Dutch public funds is entitled to make that work publicly available for no consideration following a reasonable period of time after the work was first published, provided that clear reference is made to the source of the first publication of the work.

This publication is distributed under The Association of Universities in the Netherlands (VSNU) 'Article $25 \mathrm{fa}$ implementation' project. In this project research outputs of researchers employed by Dutch Universities that comply with the legal requirements of Article $25 \mathrm{fa}$ of the Dutch Copyright Act are distributed online and free of cost or other barriers in institutional repositories. Research outputs are distributed six months after their first online publication in the original published version and with proper attribution to the source of the original publication.

You are permitted to download and use the publication for personal purposes. All rights remain with the author(s) and / or copyright owner(s) of this work. Any use of the publication or parts of it other than authorised under article $25 \mathrm{fa}$ of the Dutch Copyright act is prohibited. Wageningen University \& Research and the author(s) of this publication shall not be held responsible or liable for any damages resulting from your (re)use of this publication.

For questions regarding the public availability of this article please contact openscience.library@,wur.nl 


\title{
Research Paper
}

\section{Materials with switchable radiometric properties: Could they become the perfect greenhouse cover?}

\author{
Esteban Baeza*, Silke Hemming, Cecilia Stanghellini \\ Wageningen University \& Research, Business Unit Greenhouse Horticulture, Droevendaalsesteeg 1, 6708, PB, \\ Wageningen, the Netherlands
}

\section{A R T I C L E I N F O}

Article history:

Received 10 July 2019

Received in revised form

13 February 2020

Accepted 19 February 2020

Keywords:

Near infrared

Far infrared

Photosynthetic active radiation

Smart materials

Greenhouse climate

Modelling
Greenhouses shelter the crop from unfavourable environmental conditions and the covering largely contributes to creating beneficial growing conditions inside. There is no perfect greenhouse cover for all combinations of crop and climatic regions. Usually a greenhouse cover has permanent optical properties determining the amount of solar radiation entering the greenhouse. Consequently during crop growth, the amount and quality (spectrum, direct/diffuse ratio) of the solar radiation is not ideal for the crop. Growers try to compensate for this by using different additional techniques such as temporary coatings, screens (mobile or fixed, etc.) and heating or cooling. New materials are currently being developed, whose optical properties can be (almost) instantaneously changed (materials with switchable properties). This will allow growers to gain real-time control on the quantity and quality of the light entering the greenhouse to match crop requirement. The present study uses advanced simulation models to predict the potential of covers with switchable properties to improve tomato yield and use of resources in different climatic regions (mild winter and tropical) and with different greenhouse types (artisan and industrial type). Results indicate that covers with switchable properties have advantages over permanent properties for most combinations of filter type/location. Only in very extreme tropical climates will covering materials with permanent filter properties have advantages. Furthermore, simulations models can play a major role in optimising the switchable filter design.

@ 2020 IAgrE. Published by Elsevier Ltd. All rights reserved.

\section{Introduction}

\subsection{Greenhouse energy balance}

Greenhouses are used to shelter crops from unfavourable environmental conditions, while creating beneficial growing conditions inside. Vegetables for fresh consumption are increasingly produced under protected cultivation. The total area worldwide is estimated to be around.

3.220.000 ha, of which about 65.000 ha are high-technology greenhouses which most often are glass-covered (Hickman, 2018, p. 170; van Rijswick, 2018). Crop production is driven by different growth factors, among which light, $\mathrm{CO}_{2}$, water are essential for photosynthesis, while temperature influences

\footnotetext{
* Corresponding author.

E-mail address: esteban.baeza@wur.nl (E. Baeza).
} 


$\begin{array}{ll}\text { Nomenclature } \\ \text { Symbols } \\ \alpha & \text { Cover absorptivity of solar radiation }(-) \\ \tau & \text { Cover transmissivity of solar radiation }(-) \\ \rho & \text { Cover reflectivity of solar radiation }(-) \\ \varepsilon & \text { Cover emissivity of thermal radiation }(-) \\ \text { I } & \text { Solar radiation intensity }\left(\mathrm{W} \mathrm{m}^{-2}\right) \\ \mathrm{C}_{\mathrm{p}} & \text { Specific heat coefficient }\left(\mathrm{J}^{-1} \mathrm{~K}^{-1}\right) \\ \text { fac } \text { BAND } & \text { Fraction of total incoming radiation in a specific } \\ & \text { band (PAR, NIR and TIR) }(-) \\ \text { T } & \text { Air temperature }\left({ }^{\circ} \mathrm{C}\right) \\ \text { Subscripts } \\ \text { sun } & \text { Solar spectrum } \\ \text { dir } & \text { Direct radiation } \\ \text { diff } & \text { Diffuse radiation } \\ \text { Abbreviations } \\ \text { DSSC } & \text { Desensitised solar cell } \\ \text { HVAC } & \text { Heating, ventilation and air conditioning } \\ \text { LED } & \text { Light emitting diode } \\ \text { OLED } & \text { Organic light emitting diode } \\ \text { PAR } & \text { Photosynthetically active radiation spectrum } \\ \text { TIR } & \text { Thermal infrared radiation } \\ \text { UV } & \text { Ultraviolet spectrum } \\ \text { NIR } & \text { Near infrared radiation spectrum } \\ \text { TIR } & \text { Thermal infrared radiation spectrum } \\ & \end{array}$

crop growth and development and air humidity mainly affects disease incidence. A greenhouse is basically an efficient solar collector, thanks to its transparent cover (Boulard \& Baille, 1987; Hemming, Kempkes, \& Mohammadkhani, 2011; Zhang, Gauthier, de Halleux, Dansereau, \& Gosselin, 1996). The main source of energy is solar radiation which, concerning crop production, is usually divided in three wavebands: ultraviolet radiation (UV, 300-400 nm); photosynthetically active radiation (PAR, $400-700 \mathrm{~nm}$ ) and near infrared radiation (NIR, 700-2500 nm). UV accounts for only a small fraction of solar energy at earth level but it can affect crop morphology and the behaviour of pollinators and pests, as well as the degradation of cover materials. As the contribution by UV to the energy balance is small and there is no direct effect on crop photosynthesis, the UV component of solar radiation will be neglected in this work. The rest of the solar energy is divided roughly equally between the two remaining bands: PAR and NIR. PAR is the driving force for crop photosynthesis, growth and development (McCree, 1971; Marcelis, Broekhuijsen, Meinen, Nijs \& Raaphorst, 2006a, 2006b). NIR may affect morphology and flowering (Blanchard \& Runkle, 2010), its main contribution in the greenhouse environment is energetic (Hemming et al., 2011).

The temperature within the confined environment of a greenhouse results from the balance of all energy fluxes entering and leaving it (Fig. 1). As ambient air is usually colder and drier than greenhouse air, ventilation (and leakages) carry out energy exchange both as sensible and latent heat. Additional energy fluxes out of the greenhouse are via heat conduction through the cover and exchange of radiation in the thermal infrared range (TIR, wavelength $>2500 \mathrm{~nm}$ ). Whenever the balance of these fluxes fail to maintain the desired temperature within, heating or cooling may be used to add or subtract energy to/from the greenhouse environment.

Since most fluxes occur through the greenhouse cover, its properties are essential in determining the inside climate and the amount of external resources required to maintain it within the boundaries required for good crop production. Its transmittance for the solar spectrum, $\tau_{\text {sun }}\left(\tau_{U V}+\tau_{P A R}+\tau_{N I R}\right)$ determines the input of energy whereas its "porosity" (ventilation openings and leaks), heat conduction, emission ( $\left.\varepsilon_{\text {TIR }}\right)$ and transmittance in the TIR $\left(\tau_{T I R}\right)$, determine how easily energy can escape through convective, conductive and radiative energy losses (Papadakis et al., 2000). However, as photosynthesis is the basis of any crop growth, transparency for PAR of the cover is foremost, which constraints other properties (thermal insulation, for instance).

\subsection{Greenhouse cover properties in different climatic regions}

The external climate conditions in different climatic areas in the world require different greenhouse covering properties. There is not an "ideal" greenhouse cover: properties which are useful in The Netherlands may not be useful in Morocco, Malaysia or Saudi Arabia. Greenhouse production systems typically differ in both in structure and covering material among regions (Giacomelli et al., 2012; Hemming et al., 2008; Von Zabeltitz, 2001; Von Zabeltitz \& Baudoin, 1999; Vanthoor, 2011, p. 307).

Appendix A includes a summary of the common types of protection structures used in the most relevant climate zones in the world for greenhouse production, a review of the limiting factors faced by growers in these regions during the year and how they relate the greenhouse cover properties. Finally, there is a review of the present state-of-the-art in greenhouse covers.

\subsection{Smart glazing technology}

Thanks to the huge progress in the field of material science, and liquid crystals in particular, new advanced transparent glazing materials are being developed that are able to fully adapt to the environmental conditions in a dynamic manner. This new generation of glazing materials have additional functions such as power generation, self-cleaning, self-heating, and light and radiation control. The new functions can be both permanent (low-emittance, antireflection, scratch resistance, etc.) and dynamic/switchable (chromogenic, selfcleaning, photovoltaics, luminescent, etc.) (Casini, 2018). A change in the values of the surrounding energy field, such as a variation in electrical, chemical, thermal or mechanical energy, determines colour change (chromogenic), chemical reaction (photocatalytic) or energy generation (luminescent and photovoltaic) (Sol, Timmermans, Van Breugel, Schenning \& Debije, 2018a, 2018b; Timmermans, Saes, \& Debije, 2019). Dynamic glass panes can be passive, self-regulating or active, adjustable by the user. Passive glass panes respond 


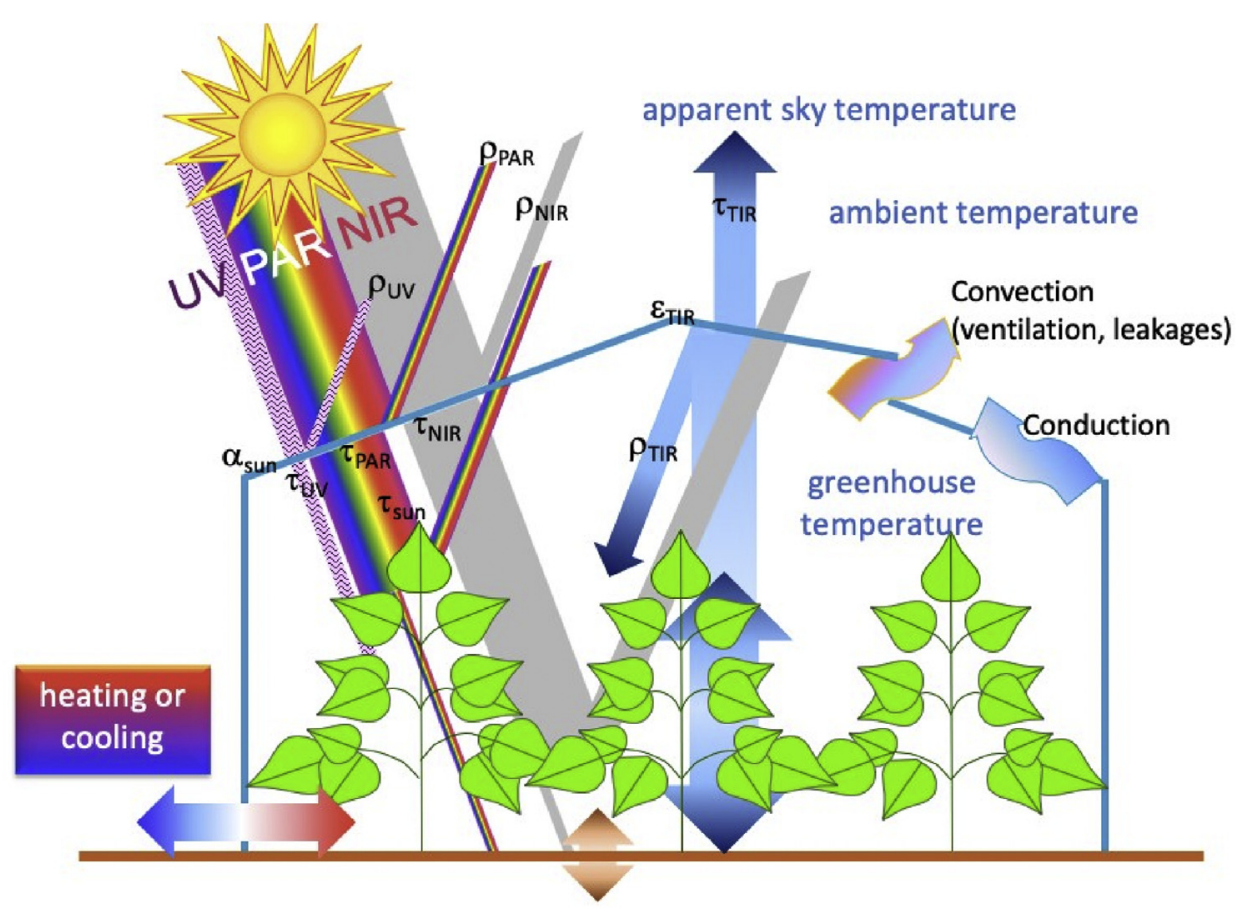

Fig. 1 - Schematic representation of the energy fluxes entering and leaving a greenhouse. The main source of energy is solar radiation (UV, PAR, NIR). Energy leaves the greenhouse as thermal radiation (TIR). Transmission $(\tau)$, reflection ( $\rho$ ) and absorption $(\alpha)$ for solar radiation determine the energy entry, transmission $(\tau)$, reflection $(\rho)$ and emission $(\varepsilon)$ for thermal radiation determine energy losses. Additional losses are sensible and latent heat through convection and sensible heat conducted through the cover. Heating or cooling are required when all this results in a too low or high greenhouse temperature.

autonomously to natural stimuli such as light (photochromic glass) or heat (thermochromic and thermotropic glass), whereas active systems change their optical characteristics in response to an electrical, user-generated stimuli (Casini, 2018) (Table 1).

The main pull for the development of these new materials comes the building industry, where, for instance, electrochromic glasses have helped in saving substantial amounts of energy for artificial lighting and cooling. However, as greenhouse cultivation might also benefit from the fine tuning and adoption of some of these materials in the cover, there is a need to explore whether greenhouses could be a potential market for such materials.

\subsection{Purpose of this paper}

The motivation of this paper is that there is a need to identify which cover properties would be useful in various climate conditions and to quantify the effect of [some of] them being switchable. The purpose of this paper is to quantify the effect of different radiative properties of the greenhouse cover on greenhouse climate, crop production and resource use. The

\section{Table 1 - Smart glazing technologies purpose and type of control (extracted from Cassini, 2018).}

\begin{tabular}{|c|c|c|}
\hline Technology & Purpose & Control \\
\hline $\begin{array}{l}\text { - Thermo-chromic materials } \\
\text { - Photo-chromic materials }\end{array}$ & $\begin{array}{l}\text { Solar radiation and glare adaptation, visual and } \\
\text { thermal comfort }\end{array}$ & Passive dynamic \\
\hline $\begin{array}{l}\text { - dispersed liquid crystals, electro kinetic pixels window) } \\
\text { Mechano-chromic materials (Elastomer-deformation } \\
\text { tuneable glass) }\end{array}$ & $\begin{array}{l}\text { Solar radiation and glare modulation, visual and } \\
\text { thermal comfort, energy savings in HVAC and } \\
\text { lighting systems }\end{array}$ & Active dynamic \\
\hline $\begin{array}{l}\text { - Electro-chromic materials (electrochromic devices, nano- } \\
\text { crystal in-glass composites) }\end{array}$ & & \\
\hline $\begin{array}{l}\text { - Chemo-chromic materials (Gas-chromic glass) Mechanical } \\
\text { actuation (Liquid infill tuneable glass }\end{array}$ & & \\
\hline $\begin{array}{l}\text { - Photoelectric materials (crystalline and inorganic thin-film } \\
\text { glazing, organic photovoltaic glazing, }\end{array}$ & & \\
\hline $\begin{array}{l}\text { DSSC photovoltaic glazing) Photo-luminous materials } \\
\text { (transparent Luminous Solar Collectors) } \\
\text { - Electro-luminous materials (transparent OLED glazing) }\end{array}$ & Solar radiation shading, energy production & Passive dynamic \\
\hline
\end{tabular}


effect of making radiative properties switchable on a specific trigger is quantified for tomato, as a model crop, in different greenhouse types typical of various climatic zones of the world.

\section{Material and methods}

\subsection{The model}

The study was carried out using a dynamic integral climate and crop growth model. KASPRO (de Zwart, 1996) has been used as a basic greenhouse climate model. KASPRO can dynamically simulate a full-scale virtual greenhouse based on the construction elements, greenhouse equipment, different covering materials and their main optical properties (transmission $\tau$, reflection $\rho$ and absorption $a$ ) and the set points for inside climate in relation to the outside climate of a given location. Outputs provided are several climate parameters, such as greenhouse air temperature, relative humidity, carbon dioxide $\left(\mathrm{CO}_{2}\right)$ concentration and resource consumption (i.e. water and energy). The model is based on the computation of relevant heat and mass balances (Bot, 1983). The heat balances describe both the convective and radiative processes. The mass balances are constituted from exchange processes of gases (air, water vapour, etc.) through leakage and ventilation (De Jong, 1990). They include canopy transpiration (Stanghellini, 1987, p. 150) and condensation on cold surfaces. The mass balances around the $\mathrm{CO}_{2}$ concentration are based on losses of $\mathrm{CO}_{2}$ by ventilation and photosynthesis, and gains of $\mathrm{CO}_{2}$ by artificial dosing and crop respiration. Greenhouse climate is controlled by a simulation of commercially available climate controllers. The total set of differential equations is solved numerically. More details on the model can be found in de Zwart (1996) with several additional modules described in Luo et al. (2005), Katsoulas, Sapounas, De Zwart, Dieleman, and Stanghellini (2015) and Graamans, Baeza, van den Dobbelsteen, Tsafaras, and Stanghellini (2018).

\subsubsection{Light transmission module}

KASPRO allocates $50 \%$ of the solar radiation to photosynthetic active light (PAR). The UV fraction is neglected, so the other $50 \%$ is attributed to NIR (Monteith, 1973). In addition to the spectral division, solar radiation is also divided into direct and diffuse components. Direct radiation reaches the earth surface with a certain angle of incidence, given by the solar position which varies during the day and seasons. The algorithm (Bot, 1983) expresses the angle of incidence of solar radiation as a function of time, latitude and longitude can be found. Diffuse radiation is omnidirectional although it has a distribution function for the intensity of radiation over the hemisphere and KASPRO uses the standard overcast sky approach (Bot, 1983). The incoming direct and diffuse radiation ( $I_{\text {dir }}$ and $I_{\text {diff, }}$, respectively) can be absorbed (a), reflected $(\rho)$ or transmitted $(\tau)$ by the greenhouse roof in different ways.

For the simulation of a specific greenhouse cover, KASPRO requires the following input: $\tau_{\mathrm{PAR}}$ (hemispherical PAR light transmission of the cover), $a_{\text {sun }}$ (solar radiation absorbed by the cover), $\tau_{\text {TIR }}$ (TIR transmission of the cover), $\varepsilon_{\text {TIR }}$ (emissivity of the cover) and $C p$ (specific heat coefficient of the cover material, J $\left.\mathrm{g}^{-1} \mathrm{~K}^{-1}\right)$. KASPRO then calculates the transmission of a multispan infinite greenhouse cover for direct radiation as a function of greenhouse geometry (roof slope, gutter distance, greenhouse orientation etc.) and solar position. A detailed description can be found in Vanthoor, (2011, p. 307). For the purpose of this paper the KASPRO model has been modified to allow for some of the optical properties of the greenhouse roof to be modified during the simulation by a trigger value. We have chosen to use air temperature. When a certain greenhouse temperature threshold is achieved, PAR transmission ( $\tau_{\text {PAR }}$ ), NIR transmission or the NIR $\left(\tau_{\text {NIR }}\right)$ and TIR transmission $\left(\tau_{T I R}\right)$ wavelength bands is decreased by a factor input by the user. The amount of radiation which is not transmitted is considered to be reflected, thus, absorption remains unaffected. For this we have introduced a new parameter in the model: fac $_{\text {BAND }}(0$ to -1) which represents the fraction of total incoming radiation in a specific band (PAR, NIR and TIR) by which both transmission of direct and diffuse radiation of the roof is decreased (and its reflection equivalently increased). For numerical stability the transmission is changed gradually over a range (P-band) of the trigger, as through a proportional controller.

\subsubsection{Basic crop yield model}

The estimation of the potential tomato dry matter production was carried out by coupling the microclimate (temperature, light, and $\mathrm{CO}_{2}$ concentration) simulated by KASPRO with the tomato yield model of Vanthoor (2011, p. 307) which is based on the photosynthesis model of (Goudriaan \& Van Laar, 1994, p. 238). The advantage of this yield model compared to others is that it accounts for the effect supra- and sub-optimal temperatures on photosynthesis and on production. This is achieved by simulating the ability of growing organs to absorb and store assimilates released from the leaves. For that, the model uses growth inhibition functions which account for the instantaneous and $24 \mathrm{~h}$ average non-optimal temperatures. The range without growth inhibition is wider for instantaneous temperature values than for $24 \mathrm{~h}$ mean temperature values. For the present study, we have used the values proposed by Vanthoor (2011, p. 307) were used, which were based on an extensive literature search. Thus, the upper boundary for unhampered instantaneous growth was $28^{\circ} \mathrm{C}$ and for the $24 \mathrm{~h}$ mean it was $22^{\circ} \mathrm{C}$. Similarly, the lower boundary for unhampered instantaneous growth was $14{ }^{\circ} \mathrm{C}$ and for the $24 \mathrm{~h}$ mean it was $18^{\circ} \mathrm{C}$.

\subsection{Optical properties of covers simulated (filters)}

As the main purpose of this study was to quantify the effect of various (and variable) radiative properties of the cover, the following filters were simulated as covering materials:

a. transmission was decreased only through an equivalent increase in reflection, since modifying absorption would have an effect on the temperature of the greenhouse roof, which would in turn have an effect on inner climate, not directly linked to the filter;

b. for the same reason, it was assumed that the change of property in one waveband would not interfere with properties in the other wavebands (unless explicitly stated), nor with heat transfer coefficient or the ventilation capacity of the roof. 
In particular, the effects of the following were simulated:

1) a spectral selective filter decreasing transmissivity (equivalent increase in reflection) in the PAR band $\left(\downarrow \tau_{P A R} / \uparrow \rho_{P A R}\right)$;

2) a spectral selective filter, decreasing transmissivity (equivalent increase in reflection) only in the NIR $\left(\downarrow \tau_{\text {NIR }} /\right.$ $\left.\uparrow \rho_{\mathrm{NIR}}\right)$;

3) decreasing transmissivity (equivalent increase in reflection) in the whole shortwave band (both PAR and NIR) $\left(\downarrow \tau_{\text {sun }} / \uparrow \rho_{\text {sun }}\right)$;

4) decreasing transmissivity (equivalent increase in reflection) of TIR radiation $\left(\downarrow \tau_{T I R} / \uparrow \rho_{\text {TIR }}\right)$.

In all simulated scenarios, except for those in The Netherlands the base material of the cover was assumed to be a typical commercial polyethylene film cover whose optical properties are listed in Table 1 . Table 2 shows a summary of the simulated filters and the factor (\%) by which greenhouse roof transmission is decreased (and reflection increased), for the three studied wavebands (PAR, NIR, combined PAR-NIR and TIR). A number of reference simulations were performed, in which the optical properties of the roof were not modified by any filter. The calculations have been done either with permanent filters, that is adapting the radiative properties of the roof during the whole crop cycle, or with switchable filters, that is adapting the radiative properties in time during the crop cycle based on a trigger. For the present study the internal greenhouse air temperature was chosen as the variable triggering the switchable filters and a P-Band of only $1{ }^{\circ} \mathrm{C}$ was selected, to ensure a rapid change in optical properties. Both for PAR and NIR filters, trigger temperature values of 26-28-30-32 ${ }^{\circ} \mathrm{C}$ were simulated and expected to decrease, while for the TIR filter, values of $16-18-20-22^{\circ} \mathrm{C}$ were used and expected to increase (see Table 3).

\subsection{Climatic regions}

The climate zones chosen were: Mediterranean climate (Agadir, Morocco) tropical/equatorial dry, desert climate (Riyadh, Saudi Arabia), humid, tropical low-land climate (Kuala Lumpur, Malaysia) and sub-arctic/temperate climate (de Bilt, the Netherlands). Figure 2 shows the monthly averages of air temperature and daily solar radiation integral for the year used in the simulations, at all three locations. It also highlights the range of conditions that are used for tomato cultivation.

Table 2 - Hemispherical transmission $\tau$, reflection $\rho$ and absorption $\alpha(\%)$ for uniformly distributed incoming radiation, in each waveband for the two simulated covering materials: polyethylene film and float glass.

\begin{tabular}{lclll} 
Scenario & Waveband & $\tau$ & $\rho$ & $\alpha$ \\
\hline Polyethylene film & PAR & 80 & 12 & 8 \\
& NIR & 80 & 12 & 8 \\
& TIR & 35 & 5 & 60 \\
Float glass & PAR & 82 & 14 & 4 \\
& NIR & 82 & 14 & 4 \\
& TIR & 0 & 15 & 85 \\
\hline
\end{tabular}

For each climatic region attributes that were a priori deemed useful were simulated, as listed in Appendix A. In all cases the prevailing type of greenhouse in the region was used as reference, that is a multi-span, glass-covered, computer controlled greenhouse for De Bilt, The Netherlands (Fig. A1, top) and a multi-span, single plastic either with controlled ventilation openings for Kuala Lumpur, Malaysia (Fig. A1, third row left) or pad and fan evaporative cooling for Riyadh, Saudi Arabia (Fig. A1, bottom left) and for Agadir, Morocco a poorly-ventilated, fixed opening "Canarian" greenhouse (Fig A1, second row, left). To keep the reasoning concerning cover properties straightforward, reference scenarios did not include any seasonal whitewash, in spite of this being common practice in both Morocco and Saudi Arabia. Appendix B includes more detailed information on the greenhouse types used in the simulations, their geometrical characteristics as well as the most relevant simulated greenhouse climate set points and cropping strategies.

\section{Results and discussion}

\subsection{PAR filter}

Figure 3 shows the effect of the permanent filter and of the best performing switchable filter for each location. Best performing is defined as the filter that induces the minimum detrimental effect or maximum beneficial effect on yield in relation to the reference.

Permanent reductions in PAR transmission resulted in clear predicted reductions in the estimated tomato yield for all the studied locations, except for Kuala Lumpur, where the results indicate the opposite, the higher the shading factor, the larger the positive effect on yield (for a maximum yield increase of $100 \%$ for the $70 \%$ PAR reduction factor). In this location, the reference production is highly penalised because of the considerable number of hours that air and crop temperature are supra-optimal $\left(\mathrm{T}>28^{\circ} \mathrm{C}\right)$. Therefore any decrease in the amount of energy entering the greenhouse (even if it is in the form of PAR radiation), translated into a positive effect on the predicted yield. This explains why many greenhouses in tropical lowlands rely on (semi)-permanent external shading screens to grow vegetable crops as tomato (Impron, Hemming \& Bot, 2008). It is also interesting to note than in the other 3 selected locations, the ratio between PAR reduction and yield reduction is variable, and is not $1: 1$, which is the value suggested by some authors for tomato cultivated under otherwise optimal growing factors (Marcelis et al., 2006a,b). Therefore, in all simulations there must be moments in the cycle where there are other limiting factors $\left(\mathrm{CO}_{2}\right.$, temperature, etc.). For instance, for Agadir the ratio is 1:0.6, for Riyadh 1:0.6 whereas for de Bilt is 1:0.9, indicating clearly thast the greenhouse climate in Agadir and Riyadh is more often suboptimal than in The Netherlands.

Making the PAR filters switchable translated into marginal yield improvements with respect to the reference in all cases except humid tropical lowland. Indeed, temperature control in a well ventilated greenhouse in The Netherlands and a cooled one in a desert was effective most of the time, and when it was not, there is little gain in reducing temperature by 
Table 3 - Summary of the simulated filters and their effect (\%) on the transmission of the greenhouse roof when fully

activated.

\begin{tabular}{|c|c|c|c|c|c|c|c|c|c|}
\hline \multirow{2}{*}{$\begin{array}{l}\text { Scenario } \\
\text { PAR filter }\end{array}$} & \multirow{2}{*}{$\frac{\text { Waveband }}{\text { PAR }}$} & \multicolumn{8}{|c|}{ Decrease factor for greenhouse roof transmission (\%) ${ }^{a}$} \\
\hline & & 10 & 20 & 30 & 40 & & 50 & 60 & 70 \\
\hline & NIR & & & & 0 & & & & \\
\hline \multirow{4}{*}{ NIR filter } & TIR & & & & 0 & & & & \\
\hline & PAR & & & & 0 & & & & \\
\hline & NIR & 12.5 & 25 & 37.5 & 50 & 62.5 & 75 & 87.5 & 100 \\
\hline & TIR & & & & 0 & & & & \\
\hline \multirow{5}{*}{$\begin{array}{l}\text { Non } \\
\text { selective } \\
\text { filter (PAR } \\
\text { and NIR) }\end{array}$} & PAR-NIR & $30-10$ & $40-10$ & $50-10$ & $60-10$ & & $70-10$ & $80-10$ & $90-10$ \\
\hline & PAR-NIR & $30-30$ & $40-30$ & $50-30$ & $60-30$ & & $70-30$ & $80-30$ & $90-30$ \\
\hline & PAR-NIR & $30-50$ & $40-50$ & $50-50$ & $60-50$ & & $70-50$ & $80-50$ & $90-50$ \\
\hline & PAR-NIR & $30-70$ & $40-70$ & $50-70$ & $60-70$ & & $70-70$ & $80-70$ & $90-70$ \\
\hline & PAR-NIR & $30-90$ & $40-90$ & $50-90$ & $60-90$ & & 70-90 & $80-90$ & $90-90$ \\
\hline \multirow[t]{3}{*}{ TIR filter } & PAR & & & & 0 & & & & \\
\hline & NIR & & & & 0 & & & & \\
\hline & TIR & 12.5 & 25 & 37.5 & 50 & 62.5 & 75 & 87.5 & 100 \\
\hline
\end{tabular}

a The decrease factor is multiplied by the transmissivity of the roof itself. For instance, for polyethylene (PE) film, with a hemispherical light transmission of the roof for PAR of $80 \%$, a decrease in PAR of $30 \%$ means the total transmission will be $0.56(0.8-0.8 \times 0.3)$.

cutting off PAR. There is, however, an obvious advantage in reducing water use for cooling in Riyhad. For instance, water consumption was reduced from $1083 \mathrm{l} \mathrm{m}^{-2} \mathrm{y}^{-1}$ in the reference scenario to $888 \mathrm{l} \mathrm{m}^{-2} \mathrm{y}^{-1}$ for the permanent filter with a $50 \%$ PAR reduction factor and $1048 \mathrm{l} \mathrm{m}^{-2} \mathrm{y}^{-1}$ for the best performing switchable filter (activation temperature $32{ }^{\circ} \mathrm{C}$ ) and PAR reduction factor of $50 \%$.
That there is little gain with respect to the reference may be more surprising for Agadir. However, the reduction of PAR radiation produced a large decrease in the energy storage in the soil. As there is no heating, this results resulted in colder night-time temperatures which offset the daytime gain.

By contrast, in the high-energy environment of Kuala Lumpur, all the simulated switchable filters also caused an

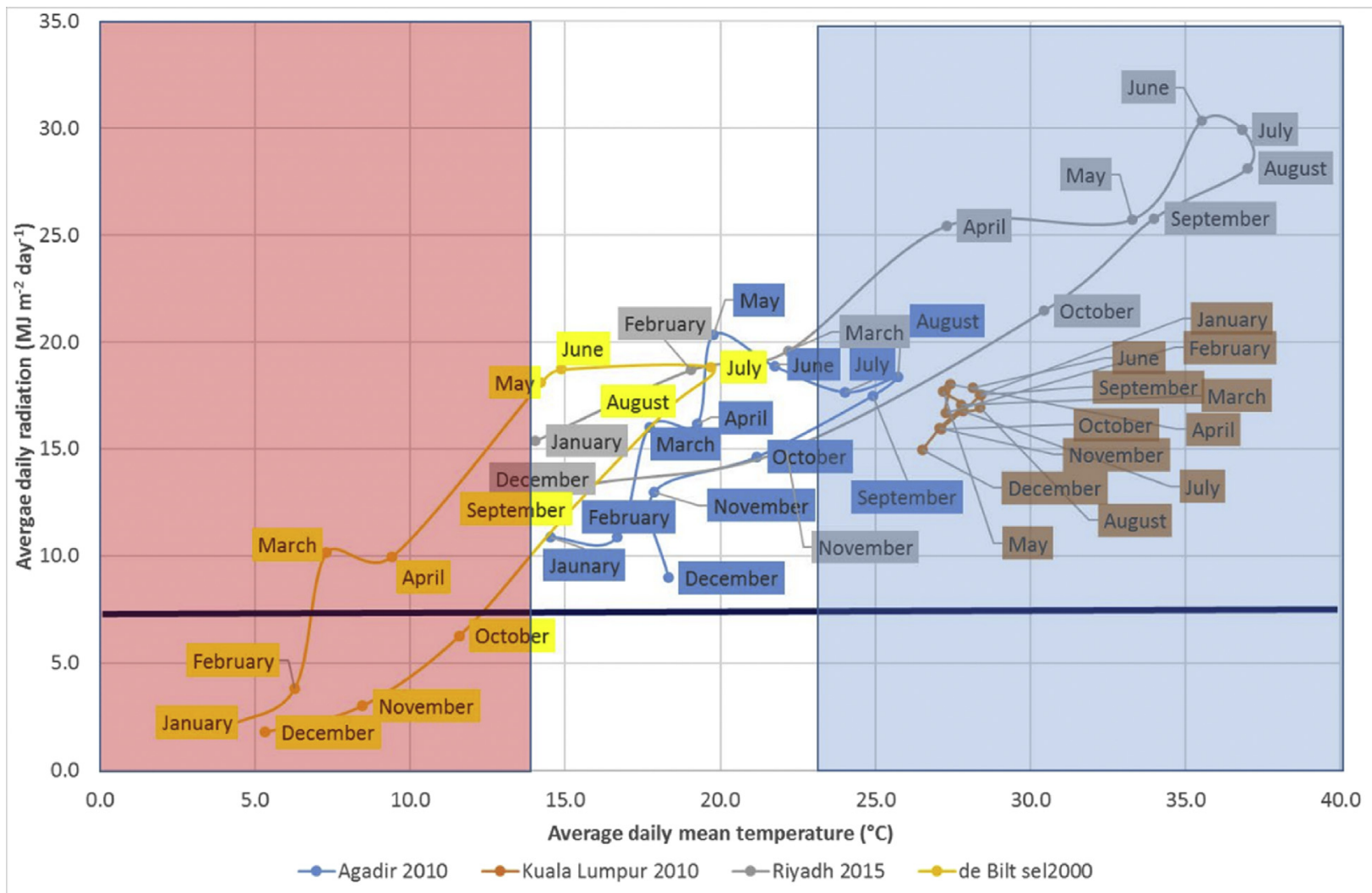

Fig. 2 - Monthly evolution of average daily solar radiation integral and average air temperature for the 4 studied locations: Agadir and Kuala Lumpur (2010), Riyadh (2015) and de Bilt (2000). The highlighted regions represent the conditions in which heating (red) or cooling (blue) should be applied in order to grow greenhouse tomato successfully; the purple line represents a threshold for minimum daily integral of solar radiation for a greenhouse tomato crop. 


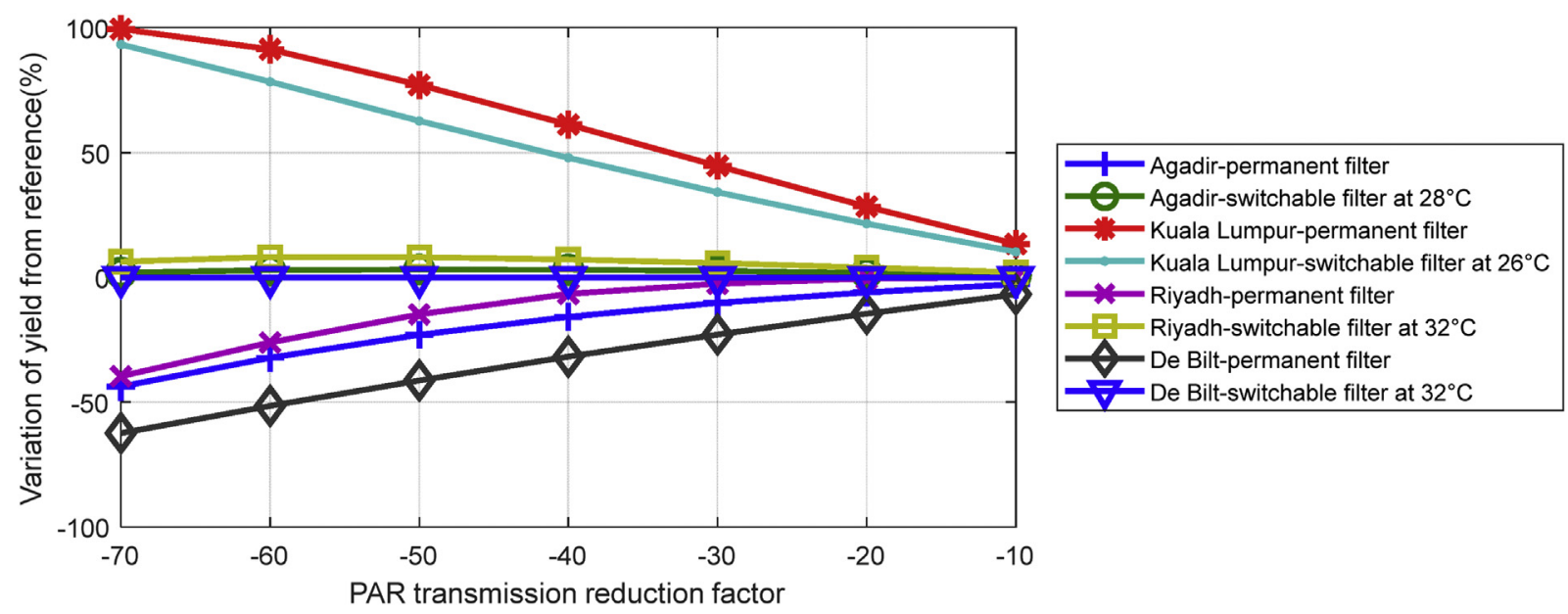

Fig. 3 - Variation of the predicted tomato yield (\%) in relation to the reference scenarios caused by different simulated PAR filters with increasing shading factor (\%): for the permanent filters and for the switchable filter with induced the minimum detrimental (or maximum beneficial) effect on yield.

increase in yield in relation to the reference, but lower than the permanent filter; the earlier the activation, the higher the increase in yield, for each simulated shading factor.

The simulated PAR filters caused a decrease of hours with supra-optimal air and canopy temperatures in relation to the reference. Canopy temperature is the value directly used by the crop growth model for the dry matter production estimation: a) for Agadir this decrease ranges between 5.5\% and $43 \%$ for the permanent filter and between $0.7 \%$ and $7 \%$ for the best performing switchable filter $\left(26^{\circ} \mathrm{C}\right)$, as shading factor increases from $10 \%$ to $70 \%$; b) for Kuala Lumpur the decrease ranges between $1 \%$ and $24 \%$ for the permanent filter and between $0.5 \%$ and $13 \%$ for the best performing switchable filter (again, the earlier activation at $26^{\circ} \mathrm{C}$ ); c) for Riyadh it ranges between $4.5 \%$ and $54 \%$ for the permanent filter and between $1.7 \%$ and $18.5 \%$ for the best performing switchable filter (also the earlier activation $26{ }^{\circ} \mathrm{C}$ ); finally, for The Netherlands, it ranges between $27.5 \%$ and $92 \%$ for the permanent filter and between $1.2 \%$ and $13 \%$ for the best performing switchable filter $\left(26^{\circ} \mathrm{C}\right)$. It can be seen that for all cases (except the very high-energy tropical lowland), the detrimental effect of reducing PAR (even in an hoc fashion) offsets any gain attained by reducing temperature, for different reasons. Nevertheless, even if it hardly increases yield, a switchable filter may reduce water consumption whenever evaporative cooling is applied. However, in locations like Agadir, where many growers chose to apply temporary shading techniques (e.g. whitewash) to decrease the levels of non-marketable product, the yield increase obtained by a PAR switchable filter could be substantial.

\subsection{NIR filter}

It follows from the above that whenever energy load can be decreased, without decreasing available PAR, there must be a positive effect. Indeed, when NIR radiation is filtered out, the simulations indicate an increased tomato yield for all the simulated scenarios with the larger the amount of NIR reflected, the higher the effect (Fig. 4). Unlike with the PAR filters, the best performing switchable filter in the four simulated climates and for all simulated shading factors, in terms of yield increase, is the earlier activated filter $\left(26^{\circ} \mathrm{C}\right)$, however, in no case there seem to be a strong argument in favour of a switchable filter. That the effect decreases with latitude (三 energy load) is not surprising. The small positive effect for de Bilt comes from the reduction of ventilation requirement, which allows for a higher carbon dioxide concentration in the greenhouses where it is artificially raised. Of course, as this limits energy gain of the greenhouse whenever ventilation is not needed, this is at the expense of using more energy for heating than the reference (1.9-25\% higher energy use for the lower reflection factor filter and the higher reflection factor simulated, respectively).

It may appear surprising, but the same yield doubling in Kuala Lumpur was obtained by $70 \%$ PAR shading with $100 \%$ reflection of NIR. The crop already has a high reflectivity for NIR radiation (about 50\%), so that NIR radiation transmitted by partial reflection (imperfect NIR filter) ends up being trapped between two reflective surfaces (covering and crop) leading to a lower reduction of the energy load than it could be expected from the NIR reflecting properties of the filter (Stanghellini, Dai, \& Kempkes, 2011).

With respect to Agadir it could be argued that reflecting NIR during the winter has a negative effect on greenhouse thermal storage, thereby causing an increase in the hours at infraoptimal temperature. However, the very poorly ventilated greenhouses there, suffer from supra-optimal daytime temperatures even during the winter, which a permanent NIR filter helps to control. Thus, one effect compensates for the other. In Fig. 5 it can be seen that the best filters (permanent and switchable) have different patterns of cropping during the year, particularly with respect to first crop in the autumn and during the winter period, which is the most profitable. The observed positive effect on yield caused by the NIR filters can be mostly attributed to the decrease in the absolute number of hours at supra-optimal temperatures, without affecting PAR transmission, which agrees with what other authors observed for different types of NIR reflecting films in hot climate 


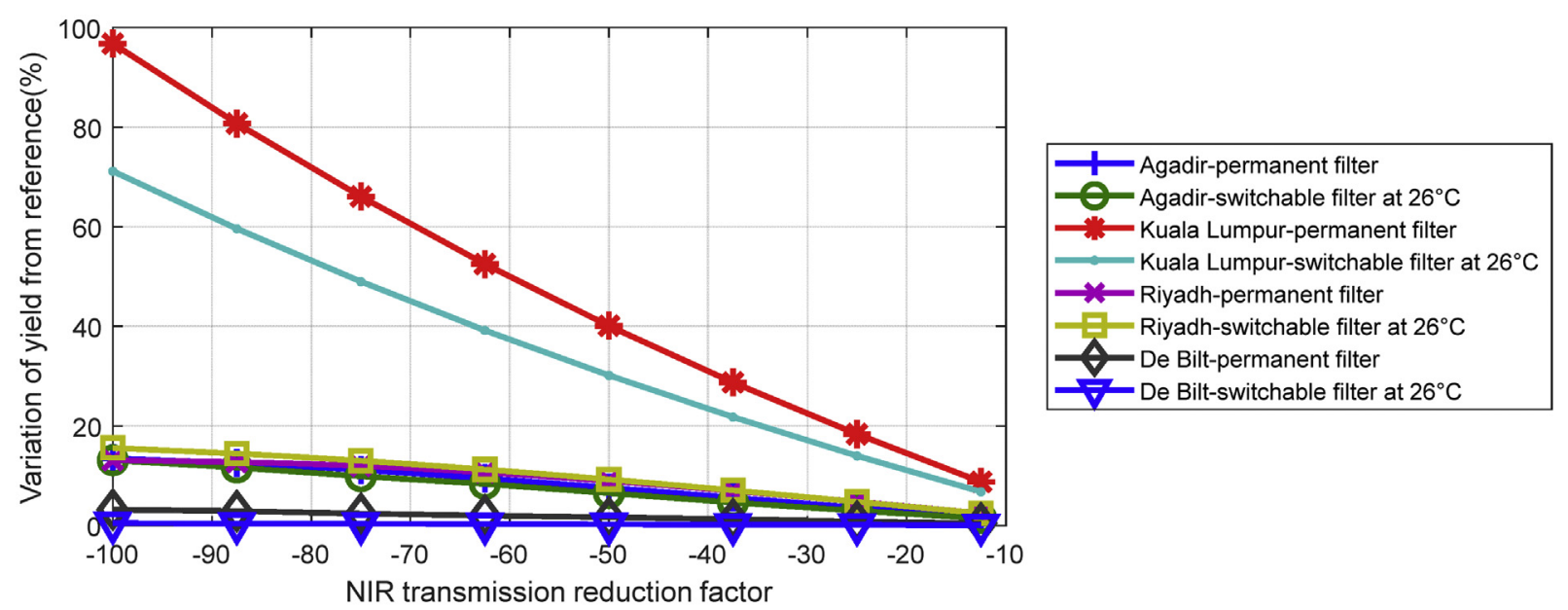

Fig. 4 - Variation of the predicted tomato yield (\%) in relation to the reference scenarios caused by different simulated NIR filters, with increasing NIR reflection factor (\%) for the permanent filters and for the switchable filter with maximum increase on yield.

conditions (García-Alonso et al., 2006; Mutwiwa, von Elsner, Tantau, \& Max, 2008). For the permanent NIR filters, the effect becomes rather high as the NIR reflection factor becomes higher, both in Agadir and Riyadh. The switchable filters have smaller effect, even when NIR is totally reflected (100\% filter) (Fig. 6).

With respect to the reduction of water used by the pad and fan evaporative cooling system in Riyadh, the NIR filters decrease the amount of water used by the PAD: i.e. for the $100 \%$ reflection filter the water saved in relation to the reference ranges between $10.2 \%$ for the latest activation filter $\left(32{ }^{\circ} \mathrm{C}\right)$ and $37.6 \%$ for the permanent filter. For Kuala Lumpur, the permanent NIR filter shows an large positive effect. As a matter of fact, different authors have pointed out the interest of the NIR reflecting covers in tropical regions (Campen, 2005; Mutwiwa et al., 2008) and in relation to the absence of any shading technique. The impossibility of using efficiently evaporative cooling techniques in these regions (unlike in the arid regions), due to the high yearround humidity, limits the potential of the simulated filters to make a more efficient use of the abundant solar radiation available. If a closed greenhouse with mechanical cooling and dehumidification would be used instead of evaporative cooling, the permanent NIR filter would surely involve and important energy saving.

The permanent NIR filters also induce an increase in relation to the reference scenario in the number of hours that the greenhouse air and canopy temperatures are infra-optimal both in Agadir and Riyadh, where a heating system has not been simulated and there are cold nights in winter. For instance, for air temperature, this increase ranges between 3\% and $41 \%$ (Agadir) and $12.5-88 \%$ (Riyadh) for the minimum and maximum simulated NIR reflection factors, respectively. On the other hand, the switchable filters in the simulations had a

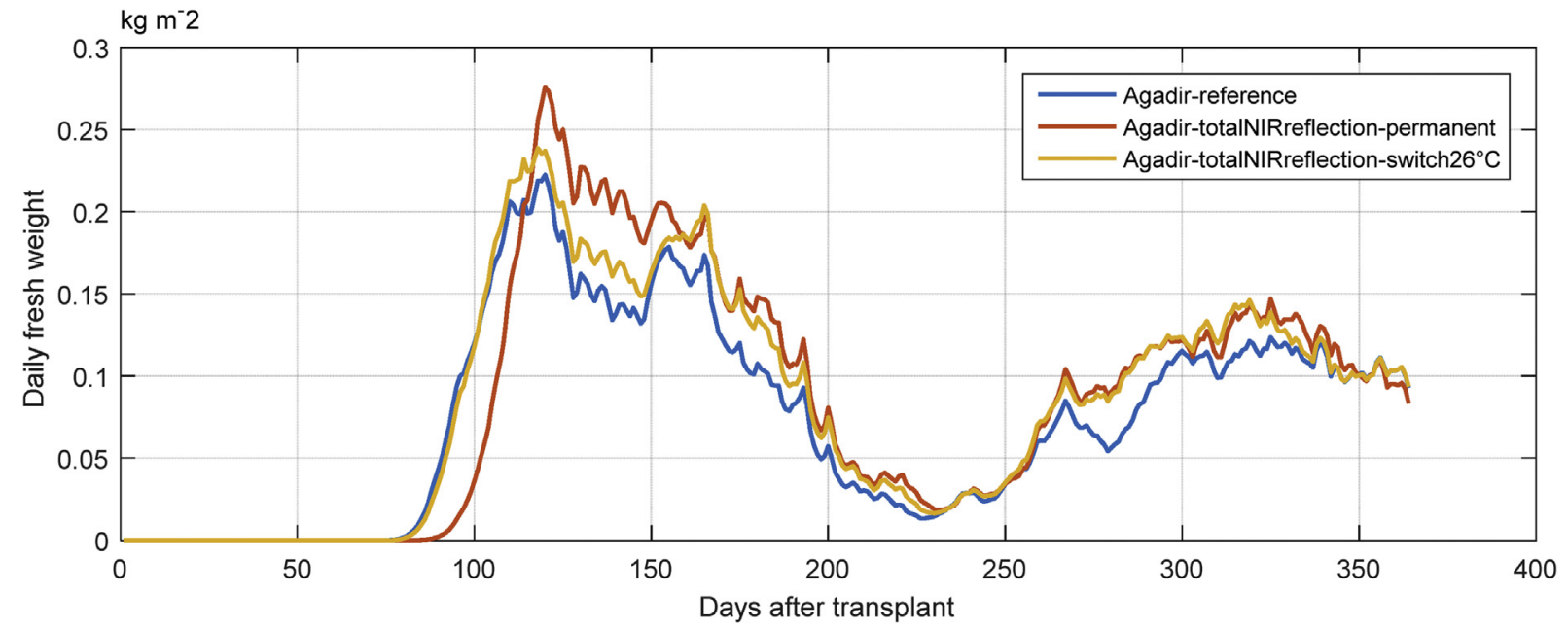

Fig. 5 - Daily evolution of fresh weight tomato production $(\mathrm{kg} \mathrm{m}-2)$ along the growing cycle for the reference scenario in Agadir and for two of the NIR reflecting simulated filters: total NIR reflection ( $100 \%)$, both a permanent and switchable at $26{ }^{\circ}$ C. Transplant date is 15 th of August. 


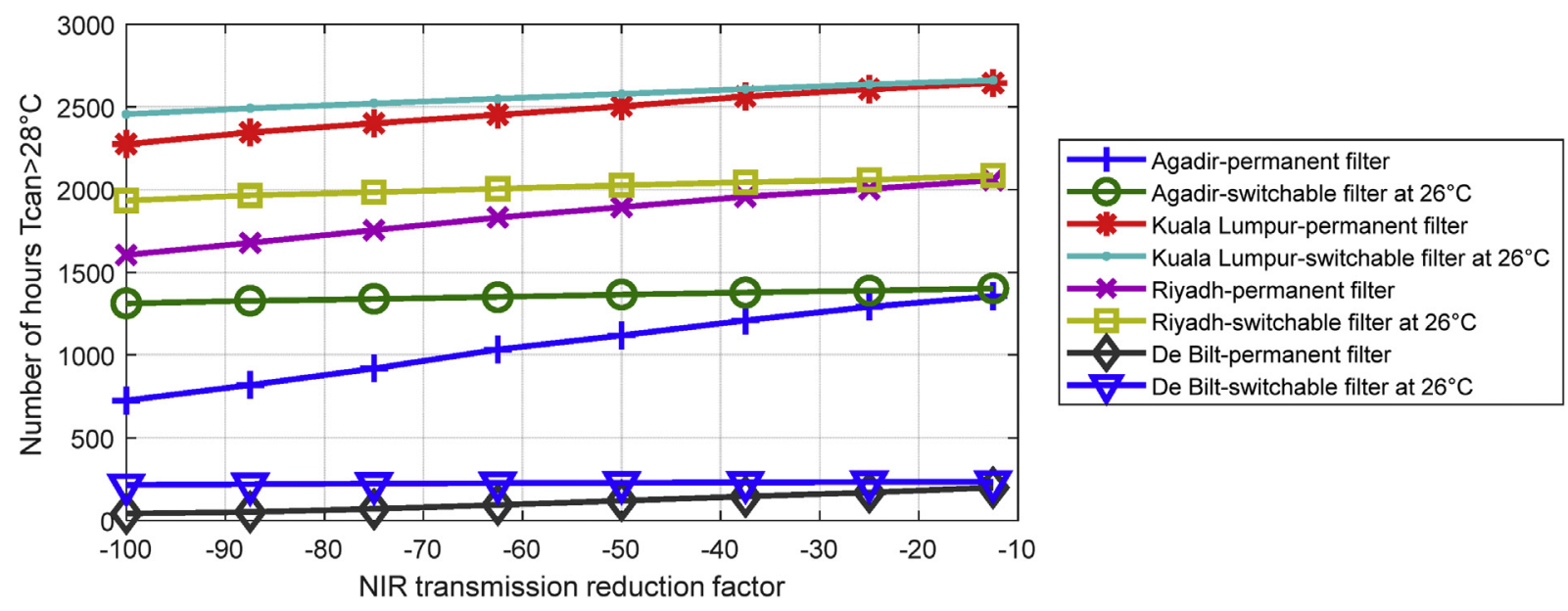

Fig. 6 - Effect of the some of the simulated NIR filters on the absolute number of hours at supra-optimal canopy temperatures with increasing NIR reflection factor (\%), for the permanent filters and for the switchable filter that has induced a maximum decrease in these hours.

very small effect on modifying the number of hours at infraoptimal temperatures. In the other locations, either the night time temperatures were not limiting (Kuala Lumpur) or the greenhouse had a heating system (de Bilt) which prevents temperatures from being infra-optimal.

Summarising, for higher latitudes a NIR filter may have use only in presence of a $\mathrm{CO}_{2}$ supply system, and even then it is debatable if the gain in yield is worth the increase in heating requirement. In "Mediterranean", unheated and poorly ventilated greenhouses a (highly) NIR reflecting cover may give a limited yield increase. However, to have the most advantage, one should consider the effect of a possible shift in the production pattern. In tropical climates, a [permanent] NIR filter has obvious advantages: it decreases water use wherever evaporative cooling is applied, and it lowers the need for a PAR cut-off in humid regions.

\subsection{PAR + NIR filter}

When both a PAR and NIR filters are used in a greenhouse cover, we see again different results depending on the studied location. However, permanent filters combining both PAR and NIR filters only outperform the NIR filters for one location, Kuala Lumpur. Here, the maximum positive effect on yield is obtained with a permanent filter that combines the maximum simulated NIR reflection (90\%) and 50\% PAR reflection. The simulated switchable filters do not improve the performance of the permanent filter, showing once again, that high temperature and high radiation in tropical lowlands can be more easily managed with permanent filters. In a better greenhouse, such as a semi-closed greenhouse with mechanical cooling, results would surely indicate that PAR reduction would not be advisable, and only NIR should be filtered out. For Agadir (Fig. 7), using a permanent filter which simultaneously reflected both PAR and NIR wavelengths, there was only a positive effect on yield when the lowest levels of PAR reflection $(<20 \%)$ were combined with the highest levels of NIR reflection $(>50 \%)$. For the rest of combinations the effect on yield was negative. The switchable filter with an activation temperature of $26^{\circ} \mathrm{C}$ (the best simulated switchable filter in terms of positive effect on yield), showed a positive effect for all the simulated combinations, with maximum values achieved as NIR reflection increases and PAR reflection decreases and vice versa.

In Riyadh, the results were very similar to those obtained for Agadir, with the exception that in this case, the switchable filters that cause a better effect on yield were the ones activated at a temperature of $28{ }^{\circ} \mathrm{C}(+15 \%$ increase in yield in relation to the reference for the combination $10 \%$ PAR reduction and $90 \%$ NIR reduction), which suggests that the pad and fan provided good control of temperature for most of the time and that PAR reduction is really not needed as the yield increase was the same as the one obtained with $100 \%$ NIR reduction. The simulations indicate and extra water saving achieved with this switchable filter close to $19 \%$.

As it was to be expected, in Agadir, Riyadh and de Bilt, the permanent PAR + NIR filters all caused decreases in yield, and the switchable filters all indicate that the best results are obtained by combining the maximum NIR reflecting factor with the minimum PAR reflecting factor. Adding PAR reflection does not improve the yield results of a selective NIR filter, according to our models. On the other hand, whitewash of the cover in spring-summer is widely used in "Mediterranean" climates, to minimise non marketable crop (García-Balaguer, Sánchez-Guerrero, Medrano, Baeza, Sánchez-González, Porras, Giménez \& Lorenzo, P, 2017) something not included in the present model. Under such conditions, a switchable filter combining PAR and NIR would be very competitive against the use of such temporary coatings, as it would ensure optimal control of supra-optimal temperatures while maximising the PAR integral.

Finally, it should be highlighted that for some shade loving crops, unlike for tomato, a switchable PAR + NIR filter could be an excellent alternative to the existing techniques used nowadays by growers, which involve heavy levels of temporary shading by whitewash or mobile screens. 


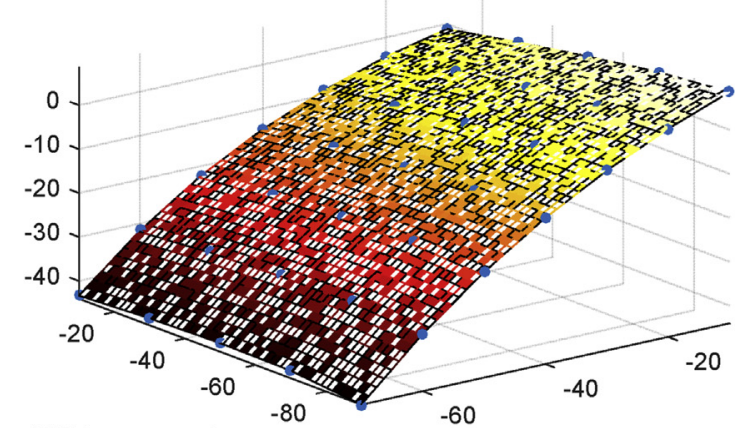

NIR transm. red

PAR transm. red.

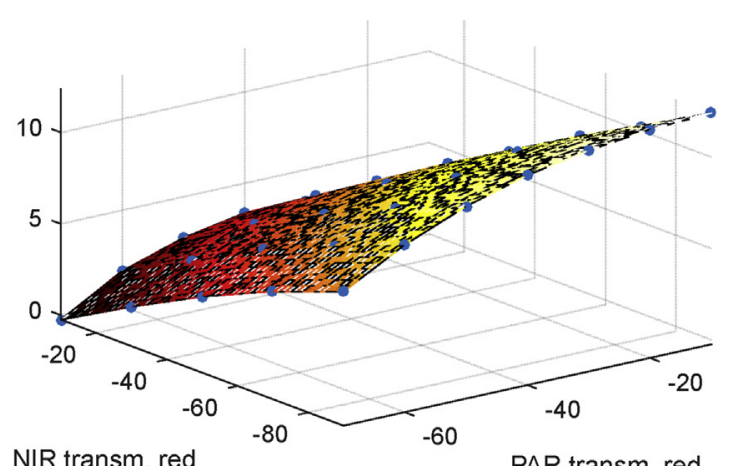

NIR transm. red

PAR transm. red.

Fig. 7 - Surface plot of the effect on yield variation (\%) in relation to the reference of using different filters that combine a simultaneous reflection of both PAR and NIR with different reflection factors in Agadir: a permanent filter (left) and a switchable filter activated at $26{ }^{\circ} \mathrm{C}$ air temperature (right).

\subsection{TIR filter}

Whenever there is an excess of energy, any decrease in the TIR transmissivity which is already low for the greenhouse cover materials in Table 2 must be considered as a serious (Fig. 7). In the regions where cold nights do limit productivity (Mediterranean, desert) a decrease in TIR transmissivity would be beneficial, but then it should be reversed during day time, when there is an excess of energy, as can be observed in Fig. 8. Nevertheless, the positive effect is very limited and only observed for the highest levels of reflection, which indicates that in Agadir, night time temperatures in winter are not very limiting.

The simulated TIR filters cause both an increase in minimum greenhouse temperatures and a decrease in the number of hours that air and canopy temperatures are infra-optimal in both Agadir and Riyadh, which are the two passive greenhouses in locations which experience cold nights during the growing period. The larger the TIR reflection factor (\%), the larger the positive effect on minimum temperatures. The decrease in the number of hours at infra-optimal temperatures in relation to the reference ranges between 12 and $88 \%$ for Agadir and between 6\% and 91\% for Riyadh, for the lowest and highest TIR reflection factors, respectively. On the other hand, the drawback of using permanent TIR filters is an increase in the number of hours at supra-optimal temperatures. The higher the TIR reflection factor, the higher the increase. As an example, for full TIR reflection, the increase ranges between $9.1 \%$ for Riyadh and $54.6 \%$ for Agadir. However, the increase in temperature obtained is more limited $\left(2-3{ }^{\circ} \mathrm{C}\right)$, maybe helping to bring temperatures slightly above the threshold, but still far from optimum for night time, therefore the positive effect on yield calculated by the model, is rather limited. In conclusion, for three of the four simulated locations (Agadir, Riyadh and Kuala Lumpur), having a permanent TIR filter seems to be highly counterproductive (Fig. 7). In Agadir and Riyadh, the net effect of the filter on yield is the result of a decrease of hours at infra-optimal temperatures in winter, and an increase of hours at supra-optimal temperatures in summer. The simulated TIR filters also induce and increased crop earliness (data not shown), which is also very valuable, since product prices in the period November to February are the highest for greenhouse in locations like

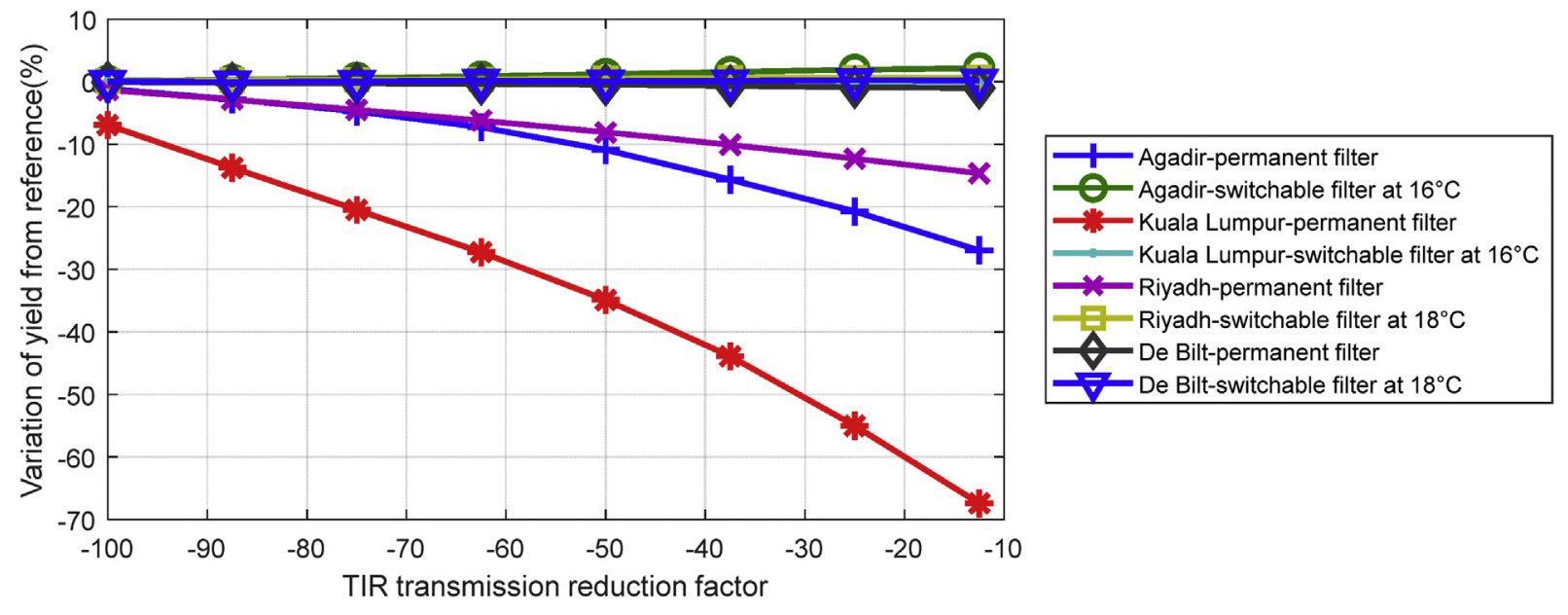

Fig. 8 - Variation of the predicted tomato yield (\%) in relation to the reference scenarios caused by different simulated TIR filters with increasing TIR reflection factor (\%): for the permanent filters and for the switchable filter with induced the minimum detrimental (or maximum beneficial) effect on yield on each simulated location. 
Agadir, thanks to export to Europe. If the most important cropping period is in winter, and the greenhouse is well ventilated, a permanent TIR filter might then be worth considering. Using switchable filters, that can be de-activated during daytime hours to allow for efficient radiative cooling, causes only a small improvement in yield in relation to the reference. It must be highlighted that our reference material in the simulations for Agadir is a thermic PE which is already absorbing a high amount of TIR, with the subsequent beneficial effect on internal air temperature. But in any case, the results in the cases of Agadir and Riyadh, prove that TIR reflection is a better option to maintain night time crop temperature higher in passive greenhouses than cover TIR absorption, which is in agreement with (Nijskens, Deltour, Coutisse, \& Nisen, 1984) and (Piscia, 2012) which it might help in preventing condensation and consequently the incidence of disease.

In The Netherlands greenhouses are heated, so the benefit of using permanent filters is a reduction of energy use compared to the reference of $27.5 \%$ (for the permanent $100 \%$ reflecting factor filter). In summer, however, the combination of not so limiting temperatures and high ventilation capacity was enough to prevent an increase in hours at supra-optimal temperatures, but the larger ventilation requirements induce lower $\mathrm{CO}_{2}$ concentrations which translate into a negligible decrease in yield ( $<1 \%$ for the different TIR reflection factors simulated). The switchable filters, on the other hand, had a much smaller detrimental effect, with an increase which is always smaller than $10 \%$ in the number of hours at supraoptimal temperatures.

\section{Conclusions}

Simulation models can play a very important role in predicting the best optical properties and whether a possible to switch them would be desirable. The simulation results of the present study indicate that for different climates and greenhouse types, different radiometric properties of the cover have different effects on greenhouse microclimate and yield. The effect of the analysed switchable properties on yield, in relation to the reference scenarios, is a combination of the effect of increasing or decreasing the number of hours with supraoptimal and infra-optimal air and crop temperatures and the final PAR integral. It has been shown that switchable filters are a better option than permanent filters for PAR and TIR, in all cases except Kuala Lumpur, for which the permanent version of the PAR, NIR and PAR + NIR version performs better than the switchable filters. On the other hand, a good NIR filter should in all cases be highly reflecting and not interfere with PAR, but then there seems to be little advantage in it being switchable.

The model results indicate that the activation temperature that ensures the best performance of the filter may differ for different locations and greenhouse types. Therefore, there is a potential in developing switchable PAR/TIR filters, and the optimal switching temperature should be fine-tuned with the help of models for every region and greenhouse type.

\section{Acknowledgements}

This work was supported by the Dutch top sector Horticultural and Starting Materials, top sector. Agri \& Food, top sector High-tech Systems and Materials, the Dutch Ministry of Agriculture, LTO Glaskracht Nederland and is a collaboration of Wageningen University \& Research, Technical University of Eindhoven, FME, BASF, Fujifilm, Sabic, Saint-Gobain/Cultilene, Mardenkro, RKW/Hyplast and Glascom Tuinbouw.

\section{Appendix A}

In the sub-arctic/temperate climates, commercial crop production is largely in high-technology green/glasshouses, where supply of energy makes up for the shortcomings of climate. No production would be possible without heating and winter production is not possible without supply of additional light (Fig. A1, top). The typical greenhouse in the sub-tropical/ Mediterranean climate is low technology, relying on solar radiation capture for passive increase of temperature in winter, and whitewash to limit it in spring/early autumn (Fig. A1, second row). This type of greenhouse has usually (too) small ventilation, is controlled manually and has typically no summer production.

In tropical/Equatorial climate zones, plastic-covered greenhouses can be found in the (relatively) cool highlands and net/shadow houses at lower elevation, except the tropical low-lands, where impermeable covers are needed against the rain (Fig. A1, third row). Wherever elevation does not suffice to lower temperature enough, and external humidity allows for it (e.g. in desert areas), evaporative cooling is applied (Fig. A 1, bottom).

Table A1 gives an overview of the limiting factors of greenhouse crop production faced by growers in the main climatic regions of the world per season, what are the mitigating actions usually undertaken and what are the consequences. It also lists the cover properties that would potentially be useful and the existing techniques presently applied.

As the amount of sunlight changes between locations and times of the year and the day, the properties of the greenhouse covers needed to fruitfully exploit sunlight varying both in time and space. Only few technologies allow for a limited variation of properties in time. Temporary coatings, fixed or movable shading nets or screens are candidates to reduce solar radiation or reduce losses of thermal energy. Instantaneously varying properties might be useful for different crops and climates and this is the subject of this study.

During summer months, and in warmer climates, the application of NIR selective filters is considered to be advantageous (García-Alonso et al., 2006; López-Marín et al., 2008), as the energy demand for cooling can be reduced. Different materials such as plastic films or coated glass have been considered for greenhouses covers (Abdel Ghani et al., 2011; Kumar, Tiwari Madan, \& Jha, 2009), movable screens (Runkle, Heins, Jaster, \& Thill, 2002b, 2002a; Stanghellini et al., 2011) or NIR-filtering temporary coatings (Blanchard \& Runkle, 2010; Von Elsner \& Xie, 2003). 
Table A1 - Overview of the limiting factors of greenhouse crop production faced by growers in the main climatic regions of the world per season; what are the mitigating actions usually undertaken and what are the consequences; which cover properties would potentially be useful and the existing techniques presently applied. Although three major climate zones are sufficient for this purpose, there is obviously a gradient in "severity" within any climate zone.

\begin{tabular}{|c|c|c|c|c|c|c|}
\hline & \multicolumn{6}{|c|}{ Climatic regions } \\
\hline & \multirow[t]{2}{*}{ Sub-arctic Temperate } & \multicolumn{2}{|c|}{ Sub-tropic Mediterranean } & \multicolumn{3}{|c|}{ Tropic/Equatorial } \\
\hline & & & & Humid & & Desert \\
\hline Challenging season & Winter & Winter & Summer & All year & Summer & Winter \\
\hline Limiting factor & $\begin{array}{l}\text { Low temperature } \\
\text { Low light }\end{array}$ & $\begin{array}{l}\text { Marginal light \& } \\
\text { temperature }\end{array}$ & High temperature & $\begin{array}{l}\text { High temperature } \\
\text { High humidity }\end{array}$ & $\begin{array}{l}\text { High temperature } \\
\text { Low humidity }\end{array}$ & $\begin{array}{l}\text { Low night-time temperature } \\
\text { Low humidity }\end{array}$ \\
\hline $\begin{array}{l}\text { Corrective measures } \\
\text { applied }\end{array}$ & $\begin{array}{l}\text { Heating } \\
\text { Artificial light }\end{array}$ & & Whitewash & $\begin{array}{l}\text { Elevation } \\
\text { Permanent shading }\end{array}$ & Evaporative cooling & \\
\hline Consequence & $\begin{array}{l}\text { Poor/no winter production High } \\
\text { energy requirement }\end{array}$ & Poor production & No production & $\begin{array}{l}\text { Poor production } \\
\text { Low quality }\end{array}$ & High water use & Poor production \\
\hline $\begin{array}{l}\text { Useful mitigating } \\
\text { property of the cover }\end{array}$ & $\begin{array}{l}\text { High TIR reflection }\left(\rho_{\mathrm{TIR}}\right) \\
\text { Insulation } \\
\text { High PAR transmission }\left(\tau_{\mathrm{PAR}}\right)\end{array}$ & & Reduced sunlight $t$ & ransmission $\left(\tau_{\text {NIR }} \tau_{\text {sun }}\right)$ High TIR tran & $\operatorname{smission}\left(\tau_{\text {TIR }}\right)$ & \\
\hline $\begin{array}{l}\text { Competing existing } \\
\text { technologies }\end{array}$ & [Multiple] movable screens & Thermic foil Double skin & $\begin{array}{l}\text { Good ventilation } \\
\text { Whitewash }\end{array}$ & Permanent [external] shading net & Evaporative cooling & \\
\hline
\end{tabular}


In regions where heating is required, or low temperatures in winter are a limiting factor, the negative effect of a permanent NIR reflecting filter in the cold season offset any advantage it may have in the summer (Kempkes, Stanghellini, Hemming, \& Dai, 2008).

During recent decades, 'thermic' greenhouse covers have been widely used, mainly with the aim of reducing thermal TIR transmission $\tau_{\text {TIR }}$, to reduce night-time heating in passive greenhouses, or to reduce the heating demand. Different studies have shown their advantages in terms of improved crop growth and better and earlier yield (Deltour, Pirard, \& de Wergifosse, 1992; Feuilloley, Guillaume, Issanchou, \& Davenel, 1990; Garzoli \& Blackwell, 1981; Nijskens et al., 1984)

A cover with both a low $\tau_{\text {TIR }}$ and a low $\varepsilon_{\text {TIR }}$, thus a high $\rho_{\text {TIR }}$, would increase both cover and air temperature (Piscia, 2012) resulting in a decrease in heat loss and enhanced yield (Solovyev, Rabotkin, \& Kovsharov, 2015). Glass has always a low $\tau_{\text {TIR }}$ and this can be improved by additional low $\varepsilon_{\text {TIR }}$ coatings (Hemming et al., 2011). Further insulation is sometimes added during cold months by stretching a waterimpermeable, transparent film between pillars within the greenhouse, to increase thermal insulation, with the obvious drawback that it further decreases input of PAR when it is already limiting (Hernández et al., 2017).

Thermal screens have been studied by several research groups (Bailey, 1981; Cohen \& Fuchs, 1999; Teitel, Barak, \& Antler, 2009) in order to reduce thermal losses from greenhouses. Advanced greenhouse growers usually have multiple movable screens to account for different conditions (Hemming, Baeza, van Breugel, \& Mohammadkhani, 2018). Shading screens are used to limit radiation load of some crops.

Aluminium energy screens are used at night to decrease thermal radiative losses and to create a buffer between the crop compartment and outside ambient. Transparent screens used at daytime have only this second effect. If screens are movable, thermal properties are controllable in time. In general it can be concluded, that present available technologies account somehow for the local climatic and crop requirements, they often represent a compromise between what is technically possible, what is useful and what is affordable.

Recently, there has been an unprecedented evolution in material technology and the chemical industry of additives, so that "smart" polymers (Debije et al., 2012; Sol et al., 2018a, 2018b), and glasses (Casini, 2018; Jelle et al., 2012; Rezaei, Shannigrahi, \& Ramakrishna, 2017), with preselected properties are becoming available. That gives the opportunity for using greenhouse covers with attributes that could be switched on and off. In order to identify the properties that, if they were adaptable, would yield the most energy saving in Dutch greenhouses, researchers applied inverse modelling (Lee, Costola, Loonen, \& Hensen, 2013). They showed that for the purpose of energy saving $\tau_{\text {sun }}$ had the largest effect, followed by the TIR properties of the cover and its heat transfer coefficient. A study for various properties and climates is still lacking.

\section{Appendix B}

Table B.1 summarises the most relevant geometrical information on the types of greenhouse structures used for the simulations. For the Mediterranean climate (Agadir, Morocco) the traditional Canarian type greenhouse (Table B 1) was used as the reference scenario. Tomato transplant date was 15 th August and end of crop cycle on 15th June the next year, a typical cycle of this region. A subtropical/Mediterranean climate, a tropical/Equatorial dry, desert climate (Riyadh, Saudi Arabia) and a humid, tropical low-land climate (Kuala.

Lumpur, Malaysia) were also been analysed. In both these climatic regions the "reference" was a plastic, multispan with narrow spans ( $4 \mathrm{~m}$ width) with controlled roof vents (Kuala Lumpur) and an evaporative cooling system (Riyadh). The standard cooling system in the region was used as reference: pad and fan, with a fan extracting air from the greenhouse and air entering through the opposite wall via a wet pad. In particular, a maximum fan capacity of $180 \mathrm{~m}^{3} \mathrm{~m}^{-2} \mathrm{~h}^{-1}$, and a pad efficiency of $85 \%$ was assumed (Willits, 2003). For both locations a long growing period with transplant date on 1st January and end of cycle 15th December was selected. Finally, simulations for a subarctic/temperate climate, were represented by De Bilt (The Netherlands). The reference greenhouse used here is a Venlo type with a glass cover, a hot water heating system and a shading screen with an aluminium coating for energy saving purposes. The simulated tomato growing cycle in this scenario went from transplant on 23rd December to 1st December following year. One year's climate data was used in all cases. The climate data for 2010 were used for both Agadir and Kuala Lumpur, and 2015 was used for Riyadh with a typical meteorological year was used for de Bilt (The Netherlands) using the methodology proposed by (Breuer \& van de Braak, 1989). Canarian type greenhouses normally lack any kind of automation, including control of the opening and closing of the vents. Thus, the scenarios simulated for this greenhouse type considered the roof vents to be permanently open. The simulated multispan greenhouse has continuous roof vents fitted with $25 \%$ porosity insect-proof nets, folded in "concertina" shape to limit loss of ventilation capacity. In the simulations with a multispan greenhouse, opening and closing of the vents has been considered automated following the temperature and relative humidity set points shown in Table B.2. 
Table B1 - Summary of geometrical characteristics of the Canarian type greenhouse simulated

\begin{tabular}{|c|c|c|}
\hline & Canarian type & Units \\
\hline Area: & 10,000 & $\mathrm{~m}^{2}$ \\
\hline Ridge orientation: & 0 (North-South) & 。 \\
\hline Central path width: & 3 & $\mathrm{~m}$ \\
\hline Gutter height: & 5 & $\mathrm{~m}$ \\
\hline Roof slope: & 6 & $\circ$ \\
\hline Span width: & 10 & $\mathrm{~m}$ \\
\hline $\begin{array}{l}\text { Distance } \\
\text { between pillars: }\end{array}$ & 5 & $\mathrm{~m}$ \\
\hline frSunAir: ${ }^{*}$ & $1.5 \%$ & \\
\hline Leakage: & $5 \times 10^{-4}$ & $\begin{array}{l}\mathrm{m}^{3} \mathrm{~m}^{-2} \mathrm{~s}^{-1} \text { per } \mathrm{m} \mathrm{s}^{-1} \\
\text { wind speed }\end{array}$ \\
\hline Window length:"** & Continuous & $\mathrm{m}$ \\
\hline Window height:*** & 0.27 & $\mathrm{~m}$ \\
\hline fr_Window ${ }^{* * * *}$ : & 2 & $\%$ \\
\hline \multicolumn{3}{|c|}{$\begin{array}{l}\text { * \% of incoming solar radiation intercepted by structural elements of the greenhouse and converted into heat. } \\
\text { Insect screen with a porosity of } 25 \% \text {, causing a } 60 \% \text { reduction in ventilation air exchange (ventilation area) (Pérez- } \\
\text { Parra et al., 2004) was simulated. } \\
\text { Since KASPRO does not allow for the simulation of a simple opening in the roof without a "flap", a reduction factor } \\
\text { (55\%) was applied to the area of roof vents, obtained from the same study of (Pérez Parra, Baeza, Montero, \& Bailey, } \\
\text { 2004) for a "parral" type greenhouse, essentially very similar to a Canarian type greenhouse } \\
\text { Fr_Window represents the ratio (\%) between total ventilation area and the greenhouse area. }\end{array}$} \\
\hline
\end{tabular}

Table B2 - Summary of most relevant set points used in the simulations of a multispan greenhouse. Setpoint

Ventilation set points $\left({ }^{\circ} \mathrm{C}\right)$ : 2219

Hours of set point activation: Sunrise Sunset Relative humidity (\%): 

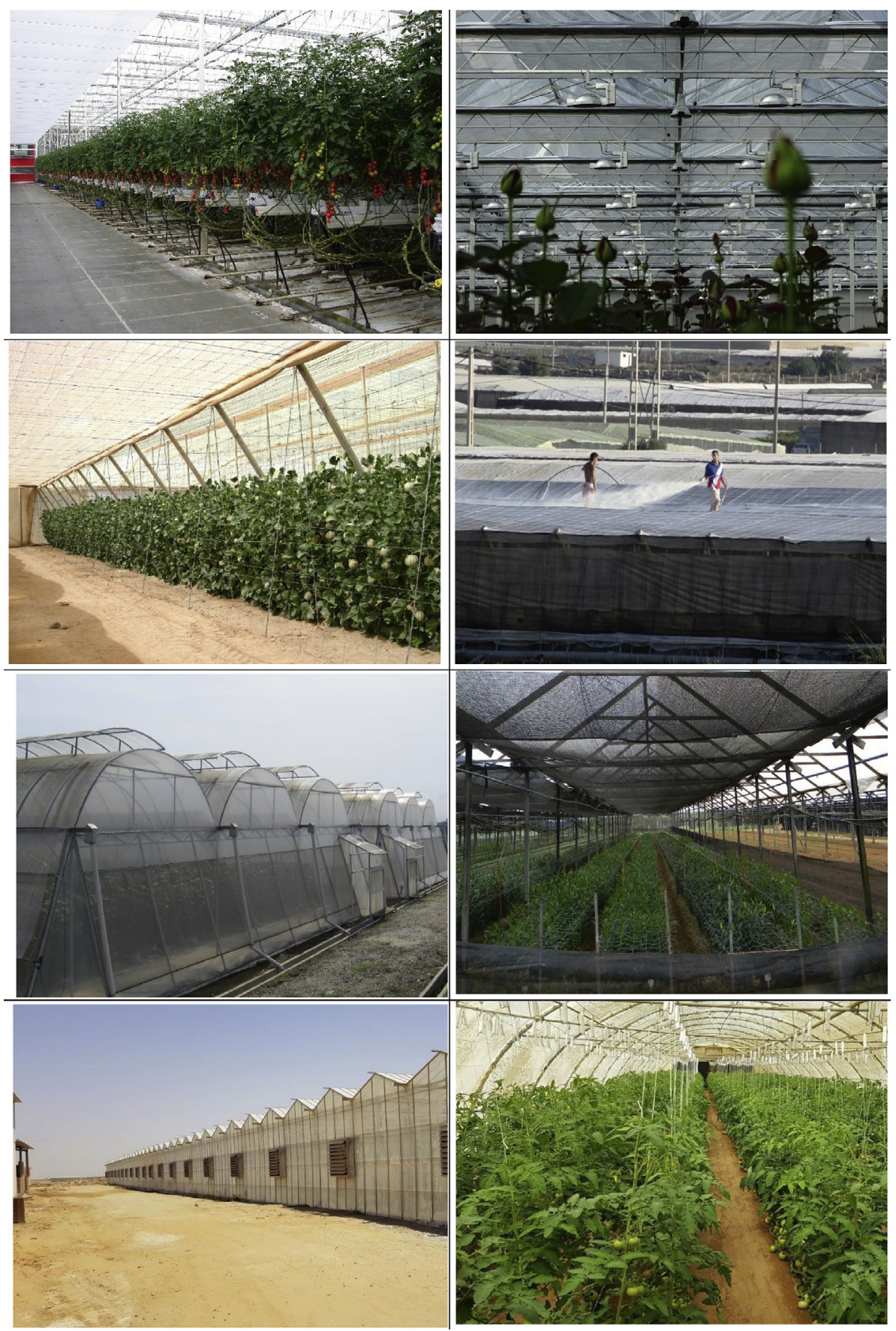

Fig. A1 - Top: sub-arctic/temperate climate.Left: tomatoes in a high-tech, heated greenhouse in The Netherlands; right: a rose crop in a Dutch greenhouse with lamps for supplemental light and partially closed shadow screen. Second row: subtropical/Mediterranean climate. Left: melon in a typical "Canarian" greenhouse in Morocco; right: "whitewash" being sprayed on the roof of a "parral" greenhouse in Almeria. Third row: Tropical/Equatorial humid climate. Left: tropical greenhouse for vegetable production in lowlands of Malaysia; right: cultivation of cut flowers in Sao Paulo state, Brasil, with permanent shading. Bottom: tropical desert climate. Left: Venlo glasshouse with pad and fan cooling system; right: tomatoes in a single tunnel cooled with pad and fan system. 


\section{R E F E R E N C E S}

Abdel-Ghany, A. M., Kozai, T., \& Chun, C. (2011). Evaluation of selected greenhouse covers for use in regions with a hot climate. Japanese Journal of Tropical Agriculture, 45, 242-250.

Bailey, B. J. (1981). The reduction of thermal radiation in glasshouses by thermal screens. Journal of Agricultural Engineering Research, 26(3), 215-224.

Blanchard, M. G., \& Runkle, E. S. (2010). Influence of NIR-reflecting shading paint on greenhouse environment, plant temperature and growth and flowering of bedding plant. Transactions of the ASABE, 53(3), 939-944.

Bot, G. (1983). Greenhouse climate: From physical processes to a dynamic model. PhD Thesis. In Wageningen Agricultural University. Institute of agricultural and environmental engineering and physics (Vol. 43)The Netherlands: AA Wageningen University. P. O. B NL-6700.

Boulard, T., \& Baille, A. (1987). Analysis of thermal performance of a greenhouse as a solar collector. Energy in Agriculture, 6(1), 17-26. https://doi.org/10.1016/0167-5826(87)90018-0.

Breuer, J. J. G., \& van de Braak, N. J. (1989). Reference year for Dutch greenhouses. Acta Horticulturae, 248, 101-108. https:// doi.org/10.17660/ActaHortic.1989.248.9. https://doi.org/ 10.17660/ActaHortic.1989.248.9.

Campen, J. (2005). Greenhouse design applying CFD for Indonesian conditions. Acta Horticulturae, 691, 419-424.

Casini, M. (2018). Active dynamic windows for buildings: A review. Renewable Energy, 119, 923-934.

Cohen, S., \& Fuchs, M. (1999). Measuring and predicting radiometric properties of reflective shade nets and thermal screens. Journal of Agricultural Engineering Research, 73(3), 245-255.

De Jong, T. (1990). Natural ventilation of large multispan greenhouses, De Jong. PhD Thesis. Wageningen University.

de Zwart, H. F. (1996). Analysing energy-saving options in greenhouse cultivation using a simulation model. PhD Thesis. Wageningen, The Netherlands: Agricultural University.

Debije, M. G., \& Verbunt, P. P. C. (2012). Thirty years of luminescent solar concentrator research: Solar energy for the built environment. Advanced Energy Materials, 2(1), 12-35. https://doi.org/10.1002/aenm.201100554.

Deltour, J., Pirard, G., \& de Wergifosse, P. (1992). Covering materials for greenhouses. Acta Horticulturae, 312, 55-62.

Feuilloley, P., Guillaume, S., Issanchou, G., \& Davenel, A. (1990). Determination of thermal transparency of plastic material for covering greenhouses. Acta Horticulturae, 281, 57-66.

García-Alonso, Y., González, A., López, J., Espí, E., Salmerón, A., \& Fontecha, A. (2006). New cool plastic films for greenhouse covering in tropical and subtropical areas. Acta Horticulturae, 719(2006), 131-137.

García-Balaguer, M. L., Sánchez-Guerrero, M. C., Medrano, E., Baeza, E. J., Sánchez-González, M. J., Porras, M. E., et al. (2017). Mobile shading versus whitewashing: Evaluation of the agronomic response of a tomato crop. Acta Horticulturae, (1170), 959-966. https://doi.org/10.17660/ ActaHortic.2017.1170.123. https://doi.org/10.17660/ ActaHortic.2017.1170.123.

Garzoli, K. V., \& Blackwell, J. (1981). An analysis of the nocturnal heat loss from a single skin plastic greenhouse. Journal of Agricultural Engineering Research, 26(3), 203-214.

Giacomelli, G. A., Sase, S., Cramer, R., Hoogeboom, J., MacKenzie, A., Parbst, K., et al. (2012). Greenhouse production systems for people. Acta Horticiculturae, 927, 2338. https:// doi.org/10.17660/ActaHortic.2012.927.1.

Goudriaan, J., \& Van Laar, H. H. (1994). Modelling potential crop growth processes. Textbook with exercises. Dordrecht: Kluwer Academic Publishers.
Graamans, L., Baeza, E., van den Dobbelsteen, A., Tsafaras, I., \& Stanghellini, C. (2018). Plant factories versus greenhouses: Comparison of resource use efficiency. Agricultural Systems, 160, 31-43. https://doi.org/10.1016/j.agsy.2017.11.003.

Hemming, S., Baeza, E. J., van Breugel, A. J., \& Mohammadkhani, V. (2018). A method to quantify the energysaving performance of greenhouse screen materials. Acta Horticulturae, 1227, 221-230. https://doi.org/10.17660/ ActaHortic.2018.1227.27.

Hemming, S., van Henten, E., van 't Ooster, B., Vanthoor, B., \& Bakker, S. (2008). The systematic design of greenhouse crop production systems. Insight, 11(429), 29-38. https://doi.org/ 10.1002/inst.200811429.

Hemming, S., Kempkes, F. L. K., \& Mohammadkhani, V. (2011). New glass coatings for high insulating greenhouses without light losses - energy saving crop production and economic potentials. Acta Horticulturae, 893, 217-226. https://doi.org/ 10.17660/ActaHortic.2011.893.15.

Hernández, J., Bonachela, S., Granados, M. R., López, J. C., Magán, J. J., \& Montero, J. I. (2017). Microclimate and agronomical effects of internal impermeable screens in an unheated Mediterranean greenhouse. Biosystems Engineering, 63, 66-77. https://doi.org/10.1016/ j.biosystemseng.2017.08.012.

Hickman, G. W. (2018). International greenhouse vegetable production statistics. Cuesta Roble Greenhouse Consultants. https:// doi.org/10.17660/ActaHortic.2006.711.9.

Impron, I., Hemming, S., \& Bot, G. P. A. (2008). Effects of cover properties, ventilation rate, and crop leaf area on tropical greenhouse climate. Biosystems Engineering, 99(Issue 4), 553-564.

Jelle, B. P., Hynd, A., Gustavsen, A., Arasteh, D., Goudey, H., \& Hart, R. (2012). Fenestration of today and tomorrow: A state ofthe-art review and future research opportunities. Solar Energy Materials and Solar Cells, 96, 1-28.

Katsoulas, N., Sapounas, A., De Zwart, F., Dieleman, J. A., \& Stanghellini, C. (2015). Reducing ventilation requirements in semiclosed greenhouses increases water use efficiency. Agricultural Water Management, 156, 90-99. https://doi.org/ 10.1016/j.agwat.2015.04.003.

Kempkes, F. L. K., Stanghellini, C., Hemming, S., \& Dai, J. (2008). Cover materials excluding near infrared radiation: Effect on greenhouse climate and plant processes. Acta Horticulturae, 797, 477-482. https://doi.org/10.17660/ActaHortic.2008.797.69.

Kumar, K. S., Tiwari Madan, K. N., \& Jha, K. (2009). Design and technology for greenhouse cooling in tropical and subtropical regions: A review. Energy and Buildings, 41(12), 1269-1275. https://doi.org/10.1016/j.solmat.2011.08.010https:// s100. copyright.com/AppDispatchServlet?publisherName= ELS\&contentID=S_0927024811004685\&orderBeanReset=true, 2009.

Lee, C., Costola, D., Loonen, R., \& Hensen, J. (2013). Energy saving potential of long-term climate adaptive greenhouse shells. In Proceedings IBPSA BS2013, 25-28 augustus 2013, Chambery, France (pp. 1-8).

López-Marín, J., González, A., García-Alonso, Y., Espí, E., Salmerón, A., \& Fontecha, A. (2008). Use of cool plastic films for greenhouse covering in Southern Spain. Acta Horticulturae, 801(2008), 181-186.

Luo, W., de Zwart, H. F., Daii, J., Wang, X., Stangehllini, C., \& Bu, C. (2005). Simulation of greenhouse management in the subtropics. art I: Model validation and scenario study of the winter season. Biosystems Engineering, 90, 307-318.

Marcelis, L. F. M., Broekhuijsen, A. G. M., Meinen, E., Nijs, E. M. F. M., \& Raaphorst, M. G. M. (2006a). Quantification of the growth response to light quantity of greenhouse grown crops. Acta Horticulturae, 711, 97-104. https://doi.org/10.17660/ ActaHortic.2006.711.9. 
Marcelis, L. F. M., Broekhuijsen, A. G. M., Nijs, E. M. F. M., \& Raaphorst, M. G. M. (2006b). Quantification of the growth response of light quantity of greenhouse-grown crops. Acta Horticulturae, 711, 97-103. https://doi.org/10.17660/ ActaHortic.2006.711.9.

McCree, K. J. (1971). The action spectrum, absorptance and quantum yield of photosynthesis in crop plants. Agricultural Meteorology, 9, 191-216. https://doi.org/10.1016/0002-1571(71) 90022-7.

Monteith, J. L. (1973). Principles of environmental physics, 241. London: Edward Arnold.

Mutwiwa, U. N., von Elsner, B., Tantau, H. J., \& Max, J. F. J. (2008). Cooling naturally ventilated greenhouses in the tropics by near-infra red reflection. Acta Horticulturae, 801(2008), 259-266. https://doi.org/10.17660/ActaHortic.2008.801.25.

Nijskens, J., Deltour, J., Coutisse, S., \& Nisen, A. (1984). Heat transfer through covering materials of greenhouses. Agricultural and Forest Meteorology, 33(2-3), 193-214.

Papadakis, G., Briassoulis, D., Scarascia Mugnozza, G., Vox, G., Feuilloley, P., \& Stoffers, J. A. (2000). Radiometric and thermal properties of, and testing methods for, greenhouse covering materials. Journal of Agricultural Engineering Research, 77(1), 7-38. https://doi.org/10.1006/jaer.2000.0525.

Pérez Parra, J., Baeza, E., Montero, J. I., \& Bailey, B. J. (2004). Natural ventilation of parral greenhouses. Biosystems Engineering, 87(3), 355-366. https://doi.org/10.1016/j.biosystemseng.2003.12.004. ISSN 1537-5110.

Piscia, D. (2012). Analysis of night-time climate in plastic-covered greenhouses. PhD Thesis, 2012. Spain: Universitat Politecnica de Catalunya.

Rezaei, S. D., Shannigrahi, S., \& Ramakrishna, S. (2017). A review of conventional, advanced, and smart glazing technologies and materials for improving indoor environment. Solar Energy Materials and Solar Cells, 159, 26-51. https://doi.org/10.1016/ j.solmat.2016.08.026. ISSN 0927-0248.

Runkle, E. S., Heins, R. D., Jaster, P., \& Thill, C. (2002a). Environmental conditions under an experimental near infrared reflecting greenhouse film. Acta Horticulturae, 578, 181-185. https://doi.org/10.17660/ActaHortic.2002.578.21.

Runkle, E. S., Heins, R. D., Jaster, P., \& Thill, C. (2002b). Plant responses under an experimental near infra-red reflecting greenhouse film. Acta Horticulturae, 580(2002), 137-143. https:// doi.org/10.17660/ActaHortic.2002.580.16.

Sol, J. A. H. P., Dehm, V., Hecht, R., Würthner, F., Schenning, A. P. H. J., \& Debije, M. G. (2018a). Temperature-Responsive luminescent solar concentrators: Tuning energy transfer in a liquid crystalline matrix. Angewandte Chemie, 57(4), 10301033.
Solovyev, A. A., Rabotkin, S. V., \& Kovsharov, N. F. (2015). Polymer films with multilayer low-E coatings. Materials Science in Semiconductor Processing, 38, 373-380. https://doi.org/10.1016/ j.mssp.2015.02.051.

Sol, J. A. H. P., Timmermans, G. H., Van Breugel, B., Schenning, A. P. H. J., \& Debije, M. G. (2018b). Multistate luminescent solar concentrator 'smart' windows. Advanced Energy Materials, 8(12). https://doi.org/10.1002/aenm.201702922.

Stanghellini, C. (1987). Transpiration of greenhouse crops: An aid to climate management. Ph.D. dissertation. Wageningen: Agricultural University.

Stanghellini, C., Dai, J., \& Kempkes, F. L. K. (2011). Effect of nearinfrared-radiation reflective screen materials on ventilation requirement, crop transpiration and water use efficiency of a greenhouse rose crop. Biosystems Engineering, 110(3), 261-271. https://doi.org/10.1016/j.biosystemseng.2011.08.002. ISSN 1537-5110.

Teitel, M., Barak, M., \& Antler, A. (2009). Effect of cyclic heating and a thermal screen on the nocturnal heat loss and microclimate of a greenhouse. Biosystems Engineering, 102(2), 162-170. https://doi.org/10.1016/j.biosystemseng.2008.11.013.

Timmermans, G., Saes, B., \& Debije, M. (2019). Dual-responsive "smart" window and visually attractive coating based on a diarylethene photochromic dye. Applied Optics, 58, 9823-9828.

van Rijswick, C. (2018). World vegetables map. Food \& Agrubusiness, Retrieved from Rabobank Website https:// research.rabobank.com/far/en/sectors/regional-food-agri/ world_vegetable_map_2018.html.

Vanthoor, B. H. E. (2011). A model-based greenhouse design method. Ph.D. Thesis. Wageningen, The Netherlands: Wageningen University.

Von Elsner, B., \& Xie, J. (2003). Effects of interference pigments in shading paint for greenhouses. In Proceedings of the ThirtyTIRst agricultural plastics congress in grand rapids, Michigan, USA (pp. $6-16)$.

Von Zabeltitz, C. (2001). Integrated greenhouse systems for mild climates. Berlin Heidelberg: Springer Verlag. https://doi.org/ 10.1007/978-3-642-14582-7.

Von Zabeltitz, C., \& Baudoin, W. (1999). Greenhouses and shelter structures for tropical regions. FAO Plant Production and Protection Papers, 154, 125.

Willits, D. H. (2003). Cooling fan-ventilated greenhouses: A modelling study. Biosystems Engineering, 84(3), 315-329.

Zhang, Y., Gauthier, L., de Halleux, D., Dansereau, B., \& Gosselin, A. (1996). Effect of covering materials on energy consumption and greenhouse microclimate. Agricultural and Forest Meteorology, 82, 227-244. 